\title{
What Feeney Got Right: Why Courts of Appeals Should Review Sentencing Departures De Novo
}

\author{
Andrew D. Goldstein
}

Last summer, when a panel of the U.S. Court of Appeals for the First Circuit issued its initial ruling in United States $v$. Thurston, ${ }^{1}$ it plunged into a war between federal judges and Congress, as well as between district and appellate courts, over how much flexibility trial judges have to tailor criminal sentences as they see fit. The war began nearly two decades ago with the passage of the Sentencing Reform Act (SRA) of $1984^{2}$ and the subsequent enactment in 1987 of the comprehensive Sentencing Guidelines regime. $^{3}$ It flared up anew in April 2003, with the passage of the Prosecutorial Remedies and Other Tools To End the Exploitation of Children Today (PROTECT) Act of $2003,{ }^{4}$ Congress's latest attempt to rein in the discretion of sentencing judges.

Before the PROTECT Act, a district court's decision to choose a sentence that departed from the range recommended by the Sentencing Guidelines was to be given considerable deference by courts of appeals. In accordance with the Supreme Court's 1996 decision in Koon v. United States, ${ }^{5}$ appellate courts had been directed to review Guideline departures for "abuse of discretion." But the PROTECT Act's "Feeney Amendment," named after its author, Florida Representative Tom Feeney, changed the

1. 338 F.3d 50 (1st Cir. 2003), withdrawn, 358 F.3d 51 (1st Cir. 2004). The original opinion is no longer available in the Federal Reporter but can be found on the Lexis database. See United States v. Thurston, Nos. 02-1966, 02-1967, 2003 U.S. App. LEXIS 15516 (1st Cir. Aug. 4, 2003). All subsequent citations to the withdrawn opinion rely on the Lexis text.

2. Pub. L. No. 98-473, 98 Stat. 1987 (codified as amended in scattered sections of 18, 28, 42, and 47 U.S.C.).

3. See U.S. Sentencing Guidelines Manual (2003).

4. Pub. L. No. 108-21, 117 Stat. 650 (to be codified in scattered sections of $18,28,42$, and 47 U.S.C.).

5. 518 U.S. 81 (1996).

6. The circuit courts varied in their interpretations of Koon: Most relied on the case to give considerable deference to departure decisions, but others interpreted it more narrowly. See Michael Goldsmith \& Marcus Porter, Lake Wobegon and the U.S. Sentencing Guidelines: The Problem of Disparate Departures, 69 GEO. WASH. L. REV. 57, 72-73 (2000); see also Ian Weinstein, The Discontinuous Tradition of Sentencing Discretion: Koon's Failure To Recognize the Reshaping of Judicial Discretion Under the Guidelines, 79 B.U. L. REV. 493, 526-27 (1999). 
standard of review to "de novo," and seemingly invited appellate courts to regularly second-guess the sentences imposed by district judges. The Amendment, which was approved after just fifteen minutes of debate on the floor of the House of Representatives, ${ }^{7}$ quickly earned the condemnation of nearly the entire legal community. ${ }^{8}$ Until Thurston, however, courts of appeals around the country had danced around the new standard of review, asserting in case after case that their decisions would be the same using either de novo or abuse-of-discretion review. ${ }^{9}$ The First Circuit, which in the past had often led other courts of appeals when it came to sentencing decisions, ${ }^{10}$ tackled the new law head-on in Thurston.

In December 2001, a Massachusetts jury found William Thurston, the vice president of a drug-testing company, guilty of conspiring to defraud the Medicare program of over five million dollars. A direct application of the range prescribed by the Sentencing Guidelines would have given Thurston a prison sentence of between sixty-three and seventy-eight months. But Judge Harrington was moved by Thurston's extensive service to his community and was troubled by the light sentence given to the company's president (who had pled nolo contendere to the same crime). So Judge Harrington departed from the Guideline range and sentenced Thurston to just three months' incarceration, with a recommendation for community confinement." The government appealed, and by the time the First Circuit heard the case, the Feeney Amendment had become law.

In a comprehensive, twenty-five-page opinion issued on August 4, 2003, the Thurston panel exercised its new deference-free powers of review and rejected both of Judge Harrington's reasons for departing from the Guidelines, remanding with instructions to the judge to impose the statutory maximum sentence of sixty months. ${ }^{12}$ Two months later, Judge Harrington

7. See Alan Vinegrad, The New Federal Sentencing Law, 15 FED. SENTENCING REP. 310, 313 (2003).

8. See infra notes 76-79 and accompanying text.

9. See, e.g., United States v. Andrews, 353 F.3d 1154, 1157 n.3 (10th Cir. 2003), cert. denied, 72 U.S.L.W. 3599 (U.S. Mar. 22, 2004); United States v. Carter, 71 Fed. Appx. 210, 211 n.* (4th Cir. 2003) (per curiam) (unpublished decision); United States v. Semsak, 336 F.3d 1123 , 1125 (9th Cir. 2003), cert. denied, 124 S. Ct. 1161 (2004); United States v. Camejo, 333 F.3d 669, 675 (6th Cir. 2003); United States v. Tarantola, 332 F.3d 498, 500 (8th Cir.), cert. denied, 124 S. Ct. 855 (2003).

10. The First Circuit's early sentencing leadership was due in part to the presence of then-Judge Breyer, who had served as one of the original commissioners of the U.S. Sentencing Commission. The First Circuit's decisions in United States v. Diaz-Villafane, 874 F.2d 43 (1st Cir. 1989), and United States v. Rivera, 994 F.2d 942 (1st Cir. 1993), have been cited extensively by other circuit courts for their approaches to the Sentencing Guidelines. See, e.g., United States v. Broderson, 67 F.3d 452, 458 (2d Cir. 1995) (citing Rivera, 994 F.2d at 948-49); United States v. Gonzales, 929 F.2d 213, 218 (6th Cir. 1991) (citing Diaz-Villafane, 874 F.2d at 49). Judge Breyer served on the Diaz-Villafane panel and wrote the opinion in Rivera.

11. See United States v. Thurston, 358 F.3d 51, 54 (1st Cir. 2004) (describing Judge Harrington's reasons for departing).

12. United States v. Thurston, Nos. 02-1966, 02-1967, 2003 U.S. App. LEXIS 15516, at *74 (1st Cir. Aug 4, 2003), withdrawn, 358 F.3d 51 (1st Cir. 2004). In this case, the statutory 
formally refused to do so. "The Court recuses itself from this case," he wrote. "It is disinclined to mechanically impose a sentence, previously prescribed by the Court of Appeals, which is clearly contrary to the objective of the sentencing guidelines." ${ }^{3}$ In a footnote, echoing a widely held feeling among judges across the country, ${ }^{14}$ Judge Harrington added:

The newly granted authority given the Court of Appeals under the Protect Act to review de novo a departure decision renders the trial judge superfluous and with only a nominal function at disposition. This is so notwithstanding the fact that the trial judge possesses deep understanding of the case based on knowledge acquired from presiding at two complex criminal jury trials. ${ }^{15}$

The purpose of this Note is to suggest that despite Judge Harrington's comments - and the doomsday rhetoric of much of the legal communitydeparture decisions should be reviewed de novo by the courts of appeals. The "abuse of discretion" standard for reviewing Guideline departures is, I argue, a relic of the pre-Guidelines regime in which judges were authorized — and expected - to consider each offender holistically and base their decisions on any available information, including the individual's character, upbringing, and family life. ${ }^{16}$ Only the sentencing judge is situated to conduct this kind of open-ended inquiry, making deferential review on appeal appropriate. For better or worse, however, the enactment of the Sentencing Guidelines in 1987 fundamentally changed the essence of the sentencing decision from an exercise of wide-ranging discretion to an application of carefully delineated rules by which offenders are placed in categories rather than treated as individuals.

Under the Guidelines, once the facts of a given case are established, the decision to depart from a prescribed range requires determining what the Guidelines mean-what types of offenses and offenders the Guidelines are and are not intended to cover. This is, at its essence, a legal assessment that appellate courts are at least as capable of making as district courts.

maximum - sixty months-was lower than the range recommended by the Guidelines (sixty-three to seventy-eight months). If a judge chooses not to depart downward from the Guidelines when they exceed a statutory cap, the offender is sentenced to the statutory maximum. See U.S. SENTENCING GUIDELINES MANUAL $\S 5$ G1.1 (2003).

13. United States v. Thurston, 286 F. Supp. 2d 70, 72 (D. Mass. 2003) (Harrington, J.) (citation omitted).

14. See infra notes 76-79 and accompanying text.

15. Thurston, 286 F. Supp. $2 \mathrm{~d}$ at $72 \mathrm{n} .4$ (Harrington, J.) (citation omitted). The two trials that Judge Harrington mentioned are of Thurston, who was convicted, and of Gerald Cullen, the drug-testing company's senior vice president for operations, who was acquitted. Id. at 71-72.

16. See Williams v. New York, 337 U.S. 241, 247 (1949) ("A sentencing judge ... is not confined to the narrow issue of guilt. His task within fixed statutory or constitutional limits is to determine the type and extent of punishment after the issue of guilt has been determined. Highly relevant-if not essential-to his selection of an appropriate sentence is the possession of the fullest information possible concerning the defendant's life and characteristics."). 
Appellate courts may in fact be better-suited to make these determinations: Not only are they more accustomed to looking at case law across districts and circuits, ensuring more consistent nationwide application of the Guidelines, but they also enjoy the benefit of input from a panel of judges, as well as from the judge below. More importantly, only appellate courts can bring uniformity to normative judgments about the Guidelines' meanings-judgments that form the core of decisions to depart.

The Feeney Amendment's de novo standard of review recognizes these comparative institutional competencies. De novo review also has the benefit of forcing appellate courts to grapple directly with the structure and application of the Guidelines and the purposes of sentencing, as opposed to simply setting boundaries around district court decisionmaking. The courts of appeals, armed with the power of de novo review, have the opportunity to create a principled common law of sentencing departures that can fill the considerable gaps in the existing Guidelines regime.

Part I of this Note provides the background for my analysis, describing the history of appellate review of sentencing decisions from the preGuidelines regime through the enactment of the Feeney Amendment. Part II describes why de novo review is the appropriate standard for evaluating Guideline departures, given the purposes and structure of the Sentencing Reform Act, the Guidelines, and the Feeney Amendment. Part III explains why, as a matter of policy, we should embrace greater appellate involvement in sentencing. Part IV addresses the primary justifications that judges and scholars have given in support of the Koon abuse-of-discretion standard. Part V revisits the circumstances of Thurston to show what de novo review looks like in practice (and why it may not be so dangerous after all).

\section{A BRIEF History OF APPELlate REVIEW of FEDERAL SENTENCING}

\section{A. Before the Guidelines}

Until 1987, district court judges had enormous discretion to tailor criminal sentences as they saw fit. Judge Marvin Frankel, whose book Criminal Sentences: Law Without Order helped bring about the Guidelines regime, decried the "almost wholly unchecked and sweeping powers" given to sentencing judges-a system that he called "terrifying and intolerable for a society that professes devotion to the rule of law." 17 When determining a sentence, district court judges were instructed to consider not just the crime committed and the offender's relevant criminal history, but also the 
offender's whole life and character. ${ }^{18}$ Professor Kevin Reitz notes that "[w]ith such a free-form thought process in gear, there were effectively no legal principles against which a sentence could be tested on review." 19

As a result, so long as sentences fell within the (typically broad) ranges prescribed by statute, just about any sentence issued by a district court judge, for whatever reason, was likely to survive appeal. ${ }^{20}$ Judges rarely explained their sentences, and consequently sentencing decisions were made with little or no guidance from case law. ${ }^{21}$ The few appellate decisions that did exist mostly dealt not with substantive analysis of the purposes and principles underlying sentencing, but with constitutional issues such as whether the penalty constituted cruel and unusual punishment or whether the sentencing procedures violated due process. ${ }^{22}$

\section{B. The Early Guidelines Regime}

Then came the revolution. Spurred on by outrage over perceived disparities in sentencing across the country, ${ }^{23}$ Congress passed the Sentencing Reform Act of 1984 and enacted the Sentencing Guidelines in 1987. Suddenly the vast majority of sentences were not up to the discretion of individual judges, but instead were dictated by simple application of an exhaustive set of rules.

Take, for example, the federal bank robbery statute, which prescribes a maximum prison sentence of ten years for nonviolent robberies of more than $\$ 100{ }^{24}$ Before the Guidelines, a judge had discretion to sentence someone who stole, say, $\$ 500,000$ from a federally insured bank to anywhere from zero to ten years' imprisonment. Under the new regime, however, a sentencing judge must engage in a series of detailed calculations using numeric values assigned by the Guidelines. The judge must determine the "base offense level" (which for nonviolent bank robbery is six), add the number of levels corresponding to the amount stolen (fourteen for a "loss" between $\$ 400,001$ and $\$ 1,000,000$ ), and apply any further adjustments commanded by the Guidelines (if the robbery employed "sophisticated

18. See Kevin R. Reitz, Sentencing Guideline Systems and Sentence Appeals: A Comparison of Federal and State Experiences, 91 NW. U. L. REV. 1441, 1445 (1997).

19. Id.

20. See Dorszynski v. United States, 418 U.S. 424, 431 (1974) ("[O]nce it is determined that a sentence is within the limitations set forth in the statute under which it is imposed, appellate review is at an end."); see also Daniel J. Freed, Federal Sentencing in the Wake of Guidelines: Unacceptable Limits on the Discretion of Sentencers, 101 YALE L.J. 1681, 1688 (1992).

21. See Freed, supra note 20, at 1688.

22. See Reitz, supra note 18 , at 1443 .

23. See FranKel, supra note 17, at 4-6; see also KATE STITH \& JOSÉ A. CABRANES, FEAR OF JUDGING: SENTENCING GUIDELINES IN THE FEDERAL COURTS 104 (1998).

24. See 18 U.S.C. $\$ 2113($ b) (2000). 
means," for example, two more levels would be added). ${ }^{25}$ Then the judge, using the "Sentencing Table," ${ }^{26}$ must cross-reference the offense-level total with the offender's "criminal history category," which involves an equally detailed calculation based on the defendant's prior criminal record. ${ }^{27}$ Assuming this was our hypothetical bank robber's first offense, his criminal history would fall in Category $\mathrm{I}^{28}$ resulting in a prescriptive Guideline range of between thirty-three and forty-one months' imprisonment. ${ }^{29} \mathrm{Had}$ the defendant been given the two-point "sophisticated means" adjustment, his range would be forty-one to fifty-one months. ${ }^{30}$ The sentencing statute stipulates that the maximum sentence within a Guideline range shall not exceed the minimum by the greater of six months or twenty-five percent. ${ }^{31}$

While called "guidelines," the ranges dictated by the Sentencing Table are presumptive, unless a judge can find a reason to "depart." 32 The purpose of departures was to give judges the freedom to adjust sentences in those unusual cases in which the underlying circumstances differ from the assumptions that shaped the Guidelines. ${ }^{33}$ Departures, however, are limited to situations in which "the court finds that there exists an aggravating or mitigating circumstance of a kind, or to a degree, not adequately taken into consideration by the Sentencing Commission." 34 Deciding to depart thus requires analyzing the Sentencing Manual to divine what the Sentencing Commission did and did not adequately consider. This is no straightforward task, especially given the litany of undefined terms in the Guidelines and the lack of guidance from the Commission as to what "adequately taken into consideration" actually means.

In drafting the Guidelines, the Commission was unable to resolve the tensions among the competing purposes of sentencing (deterrence, incapacitation, rehabilitation, retribution), nor did it favor one purpose over the others. ${ }^{35}$ Instead, the Commission based the original Guidelines largely on past sentencing practice, using an in-depth analysis of 10,500 sentences

25. See U.S. SENTENCING GUIDELINES MANUAL $§ 2 B 1.1$ (2003).

26. Id. ch. 5 , pt. A.

27. See id. $\S \$ 4 A 1.1-.2$.

28. See id. § 4A1.1; id. ch. 5 , pt. A.

29. See id. The defendant's "offense level," absent special adjustments derived from the particular circumstances of the crime, would be $6+14=20$.

30. See id. The defendant's "offense level" would be $6+14+2=22$.

31. See 28 U.S.C. $\S 994(b)(2)(2000)$. If, however, the lower end of the Guideline range is a sentence of thirty years' imprisonment or more, the maximum may be life imprisonment. Id.

32. See 18 U.S.C. $\S 3553$ (b).

33. See U.S. SEnTENCING Guidelines MANual ch. 5 , pt. K. Some evidence suggests that, in passing the Feeney Amendment, Congress may have wrongly believed that departures constituted violations of the Guidelines. For example, the House Conference Report on the Feeney Amendment refers to the prevalence of "illegal" downward departures. PROTECT ACT, H.R. CONF. REP. NO. 108-66, at 59 (2003), reprinted in 2003 U.S.C.C.A.N. 683, 694.

34. U.S. SENTENCING Guidelines MANUAL $\$ 5 K 2.0(a)(1)(B)$ (emphasis added) (citation omitted).

35. See STITH \& CABRANES, supra note 23 , at 53. 
imposed in the federal courts in 1985 and a less detailed analysis of nearly 100,000 additional cases to determine both the relevant factors that distinguish offenders and crimes and the appropriate severity of sentences. ${ }^{36}$ But the rules crafted as a result of this analysis were not accompanied by substantive explanations. The Commission did not describe the cases it relied on to create each Guideline rule, nor did it explain the process by which it arrived at a given rule. ${ }^{37}$ As Professor Ronald Wright notes, "While most rulemaking agencies provide thorough explanations of their final rules, including the factual evidence supporting the rule, and respond to important comments from opponents, the commission's explanations for its final Guidelines are strikingly terse and conclusory." ${ }^{38}$ Professor Kate Stith and Judge José Cabranes, two leading Guidelines scholars, explain that, as a result, "courts are often without information regarding the underlying policies or objectives that the Commission is seeking to achieve through its sentencing rules." 39

Despite the opacity of their underlying meaning, however, the new rules opened the door to appellate review of sentences. When district courts departed from the Guidelines, they were required to state their reasons in open court, ${ }^{40}$ giving appellate courts a tool to evaluate the justification for any departure. Moreover, the original sentencing statute commanded courts of appeals to determine whether sentences that were "outside the applicable guideline range" were "unreasonable" (without, of course, defining "unreasonable"). ${ }^{41}$

Adding to the confusion were the conflicting signals Congress gave as to just how extensive this appellate review should be. On the one hand, Congress suggested that courts of appeals should use their powers of review to "promote fairness and rationality," "reduce unwarranted disparity," "provide case law development" of sentencing departures, and "assist the Sentencing Commission in refining the sentencing guidelines as the need arises." 42 Such directives would seem to require active appellate involvement in sentencing, and possibly de novo review of departures. On the other hand, Congress wanted "to preserve the concept that the discretion of a sentencing judge has a proper place in sentencing and should not be

36. See id. at 59.

37. See id. at 57, 94-95.

38. Ronald F. Wright, Amendments in the Route to Sentencing Reform, CRIM. JUST. ETHICS, Winter/Spring 1994, at 58, 64 (citation omitted).

39. STITH \& CABRANES, supra note 23 , at 56.

40. See 18 U.S.C. $\S 3553(\mathrm{c})$ (2000), amended by PROTECT Act, Pub. L. No. 108-21, $\S 401(\mathrm{c}), 117$ Stat. $650,669(2003)$.

41. See id. $\S 3742(\mathrm{e})(3)$, amended by PROTECT Act, Pub. L. No. 108-21, §401(d)(1), 117 Stat. 650,670 (2003).

42. COMPREHENSIVE CRIME CONTROL ACT OF 1983, S. REP. No. 98-225, at 150-51 (1983), reprinted in 1984 U.S.C.C.A.N. 3332, 3333-34. 
displaced by the discretion of an appellate court." ${ }^{, 43}$ Accordingly, the SRA directed courts of appeals to "give due regard to the opportunity of the district court to judge the credibility of the witnesses, and [to] accept the findings of fact of the district court unless they are clearly erroneous." 44 And in 1988, Congress added a requirement that courts of appeals "give due deference to the district court's application of the guidelines to the facts." 45 Thus, while Congress wanted appellate courts to control and guide sentencing discretion, it left open the question of what standard of review appellate courts should employ when evaluating departures. ${ }^{46}$

One of the first cases to provide an in-depth analysis of the appropriate standard for reviewing Guideline departures came in 1989, when the First Circuit decided United States v. Diaz-Villafane ${ }^{47}$ Wilfredo Diaz-Villafane, a first-time offender, pled guilty to possession with intent to distribute twenty grams of heroin. ${ }^{48}$ The sentencing range prescribed by the Guidelines was twenty-seven to thirty-three months' imprisonment. But because the district court determined that, among other things, DiazVillafane was an "important supplier" and had employed minors in his dealing scheme, it departed upward and sentenced him to 120 months in prison. ${ }^{49}$ On appeal, the First Circuit applied an analysis from which this Note has liberally borrowed: It gave deference to the district court's findings of fact but exercised de novo review of the determination that the case was sufficiently "unusual" to justify departure. As Judge Selya explained, "That review is essentially plenary: whether or not circumstances are of a kind or degree that they may appropriately be relied upon to justify departure is, we think, a question of law." upheld the sentencing court's departure.

Diaz-Villafane's de novo standard of review was widely adopted by other federal circuits, ${ }^{51}$ much to the dismay of many judges and

43. Id. at 150 , reprinted in 1984 U.S.C.C.A.N. at 3333.

44. 18 U.S.C. $\$ 3742(\mathrm{e})$, amended by PROTECT Act, Pub. L. No. 108-21, § 401(d), 117 Stat. $650,670-71(2003)$.

45. Act of Nov. 18, 1988, Pub. L. No. 100-690, § 7103(a)(7), 102 Stat. 4181, 4417 (amending 18 U.S.C. $\S 3742(\mathrm{e}))$.

46. This ambiguity led to a split in circuits which was later resolved by Koon. Compare United States v. Kaye, 23 F.3d 50, 52-53 (2d Cir. 1994) (employing "strict de novo review"), and United States v. Diaz-Villafane, 874 F.2d 43, 49 (1st Cir. 1989) (holding that plenary review of the decision to depart is appropriate), with United States v. Canoy, 38 F.3d 893, 908 (7th Cir. 1994) ("WW]hen a district court clearly explains the basis for its finding of an extraordinary family circumstance, that finding is entitled to considerable respect on appeal.").

47. 874 F.2d 43.

48. Id. at 45 .

49. See id. at 48.

50. Id. at 49 .

51. See Reitz, supra note 18, at 1467. Professor Reitz argues that the decision led to "spectacles of dueling discretion between the trial and appellate courts," in which appellate courts would tell district courts that while the factor they-were considering was relevant, it wasn't unusual enough to warrant a departure. Id. at 1467-68. 
scholars. ${ }^{52}$ Perhaps in reaction to the criticism, the First Circuit modified its Diaz-Villafane standard in 1993 in United States $v$. Rivera. ${ }^{53}$ Then-Chief Judge Breyer, who had served on the Sentencing Commission, held that the determination of what is "unusual" does not merit plenary review (as the Diaz-Villafane court had held), but rather merits some degree of deference. Breyer noted that in many instances,

the district court's decision ... will not involve a "quintessentially legal" interpretation of the words of a guideline, but rather will amount to a judgment about whether the given circumstances, as seen from the district court's unique vantage point, are usual or unusual, ordinary or not ordinary, and to what extent. A district court may well have a special competence in making this kind of determination, because it may have a better "feel" for the unique circumstances of the particular case before it. $^{54}$

As I explain in Parts II and IV, this analysis of the district court's "unique vantage point" misinterprets the nature of Guideline review. Three years after Rivera, however, the Supreme Court in Koon v. United States expanded on the concept of sentencing courts" "special competence," and officially removed, until the Feeney Amendment, the possibility of de novo appellate review altogether.

\section{The Koon Decision}

Koon dealt with the sentencing of two Los Angeles police officers, Stacey Koon and Laurence Powell, who had participated in the 1991 beating of Rodney King. In April 1992, the officers were found not guilty of all charges in state court; the acquittals led to the worst rioting in Los Angeles history. ${ }^{55}$ A year later, Koon and Powell were convicted in federal court of violating King's constitutional rights. District Judge Davies determined that a direct application of the range prescribed by the Guidelines would have resulted in a prison sentence of seventy to eighty-

52. See, e.g., United States v. Nelson, 918 F.2d 1268, 1276 (6th Cir. 1990) (Ryan, J., concurring) ("The Diaz-Villafane formula all but reads out of the sentence review process appropriate deference to the trial court's logic, experience, wisdom, and unique insight into the case as they are to be applied in the complex art of criminal sentencing. .. [I]t attempts to make science of what is art."); Reitz, supra note 18.

53. 994 F.2d 942 (1st Cir. 1993). The opinion by the First Circuit actually consolidated two cases-United States $v$. Rivera and United States v. Adamo-into a single opinion, expressly to offer guidance to other courts. It explained that "doing so may help to illustrate an appropriate legal analysis for "departures." Id. at 946.

54. Id. at 951 (Breyer, C.J.).

55. See Koon v. United States, 518 U.S. 81, 88 (1996) ("More than 40 people died . . , more than 2,000 were injured, and nearly $\$ 1$ billion in property was destroyed."). 
seven months. ${ }^{56}$ But Judge Davies granted two downward departures. The first was due to "Mr. King's wrongful conduct," which "contributed significantly to provoking the offense behavior"; the second was based on a combination of factors, including that the officers were "significantly burden[ed]" by having been subjected to successive state and federal prosecutions, and that the officers were not "violent" people. ${ }^{57}$ As a result of the departures, Judge Davies sentenced Koon and Powell to thirty months in prison-nearly three-and-a-half years' less time than the Guidelines recommended. ${ }^{58}$

The U.S. Court of Appeals for the Ninth Circuit affirmed the officers' convictions but, using a de novo standard of review, reversed the departures and remanded the case for resentencing. ${ }^{59}$ The Supreme Court then reversed all but two minor aspects of the Ninth Circuit's opinion, holding that courts of appeals should review departure decisions solely for abuse of discretion. ${ }^{60}$ Justice Kennedy, writing for a unanimous Court, tried to explain away the revolutionary change brought about by the Sentencing Guidelines: "It has been uniform and constant in the federal judicial tradition for the sentencing judge to consider every convicted person as an individual and every case as a unique study in the human failings that sometimes mitigate, sometimes magnify, the crime and the punishment to ensue." 61

Justice Kennedy asserted that district courts have "an institutional advantage" over appellate courts in making departure determinations because they "see so many more Guidelines cases." ${ }^{\text {"62 }} \mathrm{He}$ also dismissed the idea that appellate review of departures could contribute to a common law of sentencing: "[A] district court's departure decision involves the consideration of unique factors that are little susceptible... of useful generalization." 63

56. United States v. Koon, 833 F. Supp. 769, 785 (C.D. Cal. 1993), aff d in part, vacated in part, 34 F.3d 1416 (9th Cir. 1994), aff'd in part, rev'd in part, 518 U.S. 81.

57. Id. at $785-92$.

58. Id. at 792. Interestingly, thirty months is about the amount of time to which Koon and Powell would have been sentenced under the old Parole Commission guidelines. Interview with Dennis Curtis, Clinical Professor of Law, Yale Law School, in New Haven, Conn. (Mar. 4, 2004).

59. Koon, 34 F.3d 1416.

60. Koon, 518 U.S. at $98-100$. Several scholars have pointed out, however, that despite the Court's holding, it actually employed an exacting standard of review in assessing the departures. See, e.g., Kate Stith, The Hegemony of the Sentencing Commission, 9 FED. SENTENCING REP. 14, 14 (1996).

61. Koon, 518 U.S. at 113 (Kennedy, J.). Kennedy also wrote that, even after the Guidelines, "the district court retains much of its traditional discretion." Id. at 98.

62. Id. at 98 .

63. Id. at 99 (citations and internal quotation marks omitted). 


\section{The Feeney Amendment}

In spring of 2003, seven years after the Supreme Court trumped the Ninth Circuit in Koon, Congress fired back and passed the most sweeping changes in the sentencing regime since the enactment of the Guidelines. ${ }^{64}$ In lobbying for the Feeney Amendment, Jamie Brown, the Acting Assistant Attorney General, told legislators: "The consistency, predictability, and toughness that Congress sought to achieve in the Sentencing Reform Act... is being undermined by steadily increasing downward departures." ${ }^{.65}$ In truth, these concerns were vastly overblown. ${ }^{66}$ Yet despite the evidence-and extensive last-minute lobbying by the Judicial Conference of the United States, ${ }^{67}$ the Sentencing Commission, ${ }^{68}$ and the American Bar Association ${ }^{69}$ - Congress followed the Justice Department's lead.

64. See PROTECT Act, Pub. L. No. 108-21, 117 Stat. 650 (2003) (to be codified in scattered sections of $18,28,42$, and 47 U.S.C.).

65. Letter from Jamie E. Brown, Acting Assistant Attorney General, to Senator Orrin G. Hatch, Chairman, Senate Judiciary Committee (Apr. 4, 2003), in Letter from Justice Department Supporting Original Feeney Amendment, 15 FED. SENTENCING REP. 355, 356 (2003).

66. Although the number of downward departures has increased in recent years, this increase has been due primarily to departures granted as a result of motions by the government (given for cooperating with authorities and to expedite disposition of immigration cases in the southwest border districts). In fiscal year 2001, 54,851 offenders whose sentences the Sentencing Commission had enough data to analyze were sentenced under the Guidelines, and 19,416 of these were awarded downward departures. U.S. SENTENCING COMM'N, 2001 SOURCEBOOK OF FEDERAL SENTENCING STATISTiCS 53 tbl.26 (2002) [hereinafter 2001 SOURCEBOOK]. Of these departures, nearly 6000 were granted in the five southwest border districts (the Southern District of California, the Districts of Arizona and New Mexico, and the Western and Southern Districts of Texas). This represents more than a 300\% increase since 1991. See U.S. SENTENCING COMM'N, REPORT TO THE CONGRESS: DOWNWARD DEPARTURES FROM THE FEDERAL SENTENCING GUIDELINES 64 (2003) [hereinafter REPORT TO THE CONGRESS]. In addition, 9390 departures were granted for cooperation with authorities. 2001 SOURCEBOOK, supra, at 53 tbl.26. But neither the southwest "fast track" departures nor those granted for substantial assistance were targeted by the Feeney Amendment. See Vinegrad, supra note 7, at 314. Excluding these government-initiated departures, the actual departure rate in 2001 was in the vicinity of $10 \%$, a substantially lower rate than the $20 \%$ that Congress expected when creating the Guidelines regime. See COMPREHENSIVE CRIME CONTROL ACT OF 1983, S. REP. NO. 98-225, at $52 \mathrm{n} .71$ (1983). Furthermore, the government appealed only 25 sentencing departures in 2001. REPORT TO THE CONGRESS, supra, at 54-55. The circuit courts reversed the departures in 19 of these cases. Id.

67. See Letters to Congress from Sentencing Commissioners, Judicial Conference and Chief Justice Rehnquist, 15 FED. SENTENCING REP. 341, 343 (2003) [hereinafter Letters to Congress] (reprinting a letter from Leonidas Ralph Mecham, Secretary, Judicial Conference of the United States, to Senator Orrin G. Hatch, Chairman, Senate Committee on the Judiciary).

68. See Letters to Congress, supra note 67, at 341 (reprinting a letter from Diane E. Murphy, Chair, U.S. Sentencing Commission, et al. to Senator Orrin G. Hatch, Chairman, Senate Committee on the Judiciary, and Senator Patrick J. Leahy, Ranking Member, Senate Committee on the Judiciary).

69. See Materials from Interested Groups Opposing Original Feeney Amendment, 15 FED. SENTENCING REP. 346, 347 (2003) (reprinting Letter from Alfred P. Carlton, Jr., President, American Bar Association, to Senator Orrin Hatch, Chairman, Senate Committee on the Judiciary). 
The Feeney Amendment targeted downward departures by, among other things, severely limiting the ability of judges to depart from the Guidelines in cases involving child crimes and sexual offenses; ${ }^{70}$ reducing the number of judges serving on the Sentencing Commission; ${ }^{71}$ and, in what several judges have called an attempt to create a judicial "blacklist,",72 requiring the Commission to release data files containing judge-specific sentencing information to the Attorney General. ${ }^{73}$

Mixed in with these anti-judge provisions, however, were two requirements that could actually fix some of the longstanding problems of the Guidelines regime. First, the Amendment required district judges to state the reasons for any departure "with specificity in the written order of judgment." ${ }^{, 74}$ Before Feeney, judges were permitted to explain their departures orally. This change, which will create the first comprehensive body of sentencing case law easily accessible to judges and the Commission, is vital to the advent of meaningful appellate review and the creation of a common law of sentencing departures. Second, the Amendment overturned Koon's abuse-of-discretion standard of review. In its place, Congress directed appellate courts, in examining departures, to "review de novo the district court's application of the guidelines to the facts." 75 The remainder of this Note explains why this change is so important.

70. See PROTECT Act, Pub. L. No. 108-21, $\S 401(a), 117$ Stat. 650, 667-68 (2003) (amending 18 U.S.C. \& 3553(b) (2000)).

71. See id. $\$ 401(\mathrm{n}), 117$ Stat. at 675-76 (amending 28 U.S.C. $\S 991(\mathrm{a})$ ).

72. See Ian Urbina, New York's Federal Judges Protest Sentencing Procedures, N.Y. TIMES, Dec. 8, 2003, at BI (internal quotation marks omitted).

73. See PROTECT Act $\S 401(\mathrm{~h}), 117$ Stat. at 672 (amending 28 U.S.C. $\S 994(w)(4))$.

74. Id. $\S 401$ (c), 117 Stat. at $669-70$ (amending 18 U.S.C. $\$ 3553(\mathrm{c})(2)$ ) (emphasis added).

75. Id. $\S 401(\mathrm{~d})(2), 117$ Stat. at 670 (amending 18 U.S.C. $\$ 3742(\mathrm{e})$ ). The U.S. Court of Appeals for the Fifth Circuit recently held that the Feeney Amendment's de novo standard does not apply to appellate review of all departure determinations. See United States v. Bell, 351 F.3d 672, 675-76 (5th Cir. 2003). The court noted that the Feeney Amendment's command to "review de novo" applies only to determinations under subsections (3)(A) and (3)(B) of 18 U.S.C.A. $\$ 3742$ (e). Subsection (3)(A) refers to the district court's failure to provide a written statement of reasons if it departs, and subsection (3)(B) mandates that courts of appeals should determine whether "the sentence departs from the applicable guideline range based on a factor that-(i) does not advance the objectives set forth in section 3553(a)(2); or (ii) is not authorized under section 3553(b); or (iii) is not justified by the facts of the case." The court asserted that these provisions suggest that so long as the district court issues a written statement of reasons when it departs and bases its departure on at least one objective listed in $\S 3553$ (a)(2) (which mentions deterrence, incapacitation, retribution, and rehabilitation), the command to review de novo does not apply. See id. at 676. But the Fifth Circuit was able to reach its conclusion only by ignoring subsection (B)(iii), which requires courts of appeals to determine whether the sentence departs from the guidelines based on a factor that "is not justified by the facts of the case." I fail to see how this clause can refer to anything less than all departures. Furthermore, the court seemed to suggest that so long as the district court's sentence served a single purpose of sentencing, it had met the requirements of subsection $B(i)$. But the statute uses the plural "objectives," suggesting that courts of appeals must ensure that departures comport with the objectives of sentencing considered as a whole. 
The judiciary has expressed nearly uniform outrage over the Feeney Amendment, ${ }^{76}$ and while much of the ire has been directed at the Amendment's "blacklist" features, its de novo provision also has been roundly criticized. The Judicial Conference, in lobbying against the Amendment, wrote that abuse-of-discretion review "recognizes that district judges are better positioned to decide departures." " Lawrence Zatkoff, Chief Judge of the Eastern District of Michigan, used his September 2003 State of the Court message to explain his opposition to de novo review. Imposing a sentence, he said,

is the most difficult part of my job because of the man or woman and their family members who are standing before me awaiting sentence. That individual is not a simple mathematical equation, and not a formula to be calculated... The sentencing judge alone is in the best position to consider the totality of the defendant's situation. $^{78}$

Judge Jack Weinstein of the Eastern District of New York has begun videotaping all of his sentencing proceedings so that the court of appeals, when exercising de novo review, will be able to see the defendant as a person, not just a paper record. ${ }^{79}$

Amid all of the criticism of the Feeney Amendment, it is easy to lose sight of a critical fact: The version of the Amendment that was signed into law still leaves considerable room for sentencing departures. In its original form, the Amendment aimed to limit all downward departures to those "affirmatively and specifically identified as a permissible ground of downward departure in the sentencing guidelines or policy statements." ${ }^{, 80}$

76. See Alan Vinegrad, The Judiciary's Response to the PROTECT Act, N.Y. L.J., Jan. 8, 2004, at 4. Chief Justice Rehnquist devoted a substantial part of his 2003 year-end report on the judiciary to decrying the Amendment. See WILlIAM H. REHNQUIST, 2003 YEAR-END REPORT ON THE FEDERAL JUDICIARY (2004), http://www.supremecourtus.gov/publicinfo/year-end/ 2003year-endreport.html. In addition, several judges have used their sentencing opinions to speak out against the Amendment. See, e.g., United States v. Mellert, No. CR 03-0043 MHP, 2003 WL 22025007 , at $* 2$ (N.D. Cal. July 30,2003 ) ("[T] he wisdom of the years and breadth of experience accumulated by judges and the Sentencing Commission in adjudicating criminal cases and sentencing defendants is shucked for the inexperience of young prosecutors and the equally young think-tank policy makers in the legislative and executive branches.").

77. Letters to Congress, supra note 67 , at 343 (reprinting a letter from Leonidas Ralph Mecham to Senator Orrin G. Hatch). After the passage of the PROTECT Act, the Judicial Conference noted that the "alteration of the standard of review" was "contrary to previous positions" taken by the Conference, but did not specifically call for the provision's repeal. See Judicial Conference Seeks Restoration of Judges' Sentencing Authority, THIRD BRANCH, Oct. 2003, at http://www.uscourts.gov/ttb/oct03ttb/restoration/index.html.

78. Lawrence P. Zatkoff, Message on the State of the Court (Sept. 16, 2003), in E. Dist. of Mich. Chapter, Fed. Bar Ass'n, Thoughts on the Role of the Federal Judiciary, at http://www.fbamich.org/index.cfm?location=138\&ParentID=1 (last visited Apr. 2, 2004).

79. See Leonard Post, Two U.S. Judges Fire at 'Feeney, 'NAT'L L.J., Feb. 9, 2004, at 4.

80. 149 CONG. REC. H2420 (daily ed. Mar. 27, 2003). 
But in conference committee, this ban on unspecified downward departures was limited to child crimes and sexual offenses, ${ }^{81}$ allowing courts to retain the bulk of their departure authority. Senator Edward Kennedy explained that the Amendment was not "intended to discourage departure decisions when the unusual circumstances of a case justify a sentence outside the recommended range." 82

Therefore, despite several provisions that judges and scholars are rightly alarmed by, the Feeney Amendment cannot be construed as an allout assault on downward departures. As I argue below, the discretion to depart preserved in the Amendment, coupled with the proper and enlightened exercise of de novo review, has the potential to bring greater justice and wisdom to sentencing determinations.

\section{How DE NOVO REVIEW FITS THE CURRENT STRUCTURE OF THE GUIDELINES}

\section{A. Is Sentencing Unique?}

To begin the analysis, it is worth asking why sentencing has always been considered different from torts and contracts, fields that have engendered the creation of a common law (and have welcomed de novo review). Professor Stith and Judge Cabranes explain that sentencing has traditionally been considered unique because it is the one area of law in which justice's "blindfold" is meant to be lifted. ${ }^{83}$ When a court decides guilt or innocence (or, for that matter, whether an individual is civilly liable or has breached a contract), "it ought not to matter whether the defendant is rich or poor, whether the defendant has erred in the past, or suffered unusual disadvantages." $" 84$ But in sentencing, "Justicia must lift the blindfold," 85 for the judge is required to consider the whole individual, "to weigh all of the circumstances of the particular case." helps to explain why few limits have traditionally existed as to what evidence can be presented at sentencing hearings. In such a system, with no standardized way of assessing "the whole person," it would be difficult to have meaningful appellate review. Furthermore, evaluations that depend on an endless number of variables are not, by their very nature, useful for generalization. It is this system that the Koon Court seemed to be harkening

81. See 18 U.S.C.A. § 3553(b)(2) (West Supp. 2003).

82. 149 CONG. REC. S5119 (daily ed. Apr. 10, 2003) (statement of Sen. Kennedy), cited in Vinegrad, supra note 7, at 313.

83. STITH \& CABRANES, supra note 23 , at $78-79$

84. Id. at 78 .

85. Id. at 79 .

86. $I d$. at 78 . 
back to when writing of the need to defer to the discretion of the district judge. $^{87}$

But this system ceased to exist with the enactment of the Guidelines. As described in Section I.B, a sentencing decision now requires examining a 400-plus-page manual to determine which of forty-three "offense levels" applies to a defendant and then cross-referencing that number with the appropriate "criminal history category" to determine the appropriate sentence range. ${ }^{88}$ As Stith and Cabranes lament, "the case-by-case exercise of human judgment" has been replaced by "a mechanical calculus." 89 A crucial side effect of this revolutionary change was to remove the obstacles to meaningful appellate review. Once a trial judge determines what the relevant facts are, application of these facts to the Guidelines is primarily, as the First Circuit concluded in Diaz-Villafane, a legal analysis to which the trial judge brings no unique expertise. ${ }^{90}$

Defenders of abuse-of-discretion review point out that in certain places, the sentencing statute commands judges to evaluate defendants using the same "whole person" analysis judges employed in the pre-Guidelines era. ${ }^{91}$ Section 3553(a) directs courts to consider "the nature and circumstances of the offense and the history and characteristics of the defendant" ${ }^{\prime \prime 2}$ as well as the entire panoply of purposes for sentencing-from deterrence and incapacitation to retribution and rehabilitation. ${ }^{93}$ And $\S 3661$ states: "No limitation shall be placed on the information concerning the background, character, and conduct of a person convicted of an offense which a court of the United States may receive and consider for the purpose of imposing an appropriate sentence." 94 These clauses suggest that judges, even under the Guidelines regime, should conduct the kind of open-ended inquiry that occurred prior to the SRA and that precluded meaningful appellate review.

But appellate review is difficult only in situations in which the Guidelines do not restrict or place boundaries around the use of the "whole person" analysis. For example, a sentencing judge can use the wide-ranging information gleaned from the inquiry conducted pursuant to $\S 3553$ (a) and $\S 3661$ in choosing the length of a defendant's sentence within the specified Guideline range. The Guidelines place no boundaries around such decisions; accordingly, they typically do not face appellate scrutiny. The discretionary "whole person" analysis also comes into play after a judge

87. See Koon v. United States, 518 U.S. 81, 113 (1996).

88. See U.S. SENTENCING GuIDELINES MANUAL ch. 5, pt. A (2003).

89. STITH \& CABRANES, supra note 23 , at 82.

90. See United States v. Diaz-Villafane, 874 F.2d 43, $49-50$ (1st Cir. 1989).

91. See, e.g., Freed, supra note 20, at 1745; Marc Miller \& Daniel J. Freed, Honoring Judicial Discretion Under the Sentencing Reform Act, 3 FED. SENTENCING REP. 235 (1991).

92. 18 U.S.C. $\S 3553(\mathrm{a})(1)(2000)$.

93. See id. $\S 3553(\mathrm{a})$.

94. Id. $\S 3661$. 
has decided to depart from the Guidelines, because the sentencing statute places few restrictions (and provides little guidance) as to the extent of departures. $^{95}$ It is logical, therefore, that this decision, which the DiazVillafane court called "quintessentially a judgment call," deference" and reversed on appeal only if found to be unreasonable. ${ }^{97}$

\section{B. Why the Departure Decision Invites Active Appellate Review}

However, the decision of whether to depart at all-the central subject of the Feeney Amendment and this Note's inquiry-receives fundamentally different treatment by the Guidelines and the sentencing statute, both of which spell out in detail the factors that judges are permitted to consider in making a departure determination. Section $5 \mathrm{~K} 2.0$ of the Guidelines authorizes the sentencing court to depart from the applicable Guideline range when the court finds "that there exists an aggravating or mitigating circumstance," so long as that circumstance is "of a kind, or to a degree, not adequately taken into consideration by the Sentencing Commission in formulating the guidelines that, in order to advance the objectives set forth in 18 U.S.C. $\$ 3553(\mathrm{a})(2)$, should result in a sentence different from that described." 98

To break this down, for a court to depart from the range recommended by the Guidelines, it must (1) examine the facts of the case to see if any mitigating or aggravating circumstances exist; (2) determine what has been "adequately taken into consideration by the Sentencing Commission" by examining "only the sentencing guidelines, policy statements, and official commentary of the Sentencing Commission";, and (3) consider the purposes of sentencing listed in $\S 3553(\mathrm{a})(2)$ to determine whether a Guideline sentence is justified.

The first part of this analysis is a factual assessment that district courts are uniquely qualified to make, as it requires weighing evidence presented at trial, judging the credibility of witnesses, and assessing the testimony given at the sentencing hearing. The second and third parts of the analysis,

95. See id. § 3553(b).

96. United States v. Diaz-Villafane, 874 F.2d 43, 49 (1st Cir. 1989).

97. See 18 U.S.C.A. § 3742(e) (West Supp. 2003). 98. U.S. SENTENCING GUIDELINES MANUAL $\$$. $5 \mathrm{~K} 2.0$ (2003). The objectives set forth in
$\S 3553(\mathrm{a})(2)$ are for the sentence

(A) to reflect the seriousness of the offense, to promote respect for the law, and to provide just punishment for the offense;

(B) to afford adequate deterrence to criminal conduct;

(C) to protect the public from further crimes of the defendant; and

(D) to provide the defendant with needed educational or vocational training, medical care, or other correctional treatment in the most effective manner.

18 U.S.C. $\S 3553(\mathrm{a})(2)$. The Feeney Amendment did not change this provision.

99. 18 U.S.C. $\S 3553(\mathrm{~b})$. 
on the other hand, require examining the overall Guidelines regime and the purposes of sentencing-and these are fundamentally legal determinations. The departure decision, thus, is "the essence of a mixed question of fact and law."

In establishing standards of review for other mixed questions of fact and law, the Supreme Court has welcomed de novo review. In Ornelas $v$. United States, which was decided just two weeks before Koon, the Supreme Court, with only Justice Scalia in dissent, held that trial judges' determinations of reasonable suspicion and probable cause should be reviewed de novo on appeal. ${ }^{101}$ The Court explained that reasonable suspicion and probable cause are "fluid concepts that take their substantive content from the particular contexts in which the standards are being assessed," and that a policy of deference, allowing individual judges to determine the meaning of the Fourth Amendment, "would be inconsistent with the idea of a unitary system of law."102 The Court added that "the legal rules for probable cause and reasonable suspicion acquire content only through application. Independent review is therefore necessary if appellate courts are to maintain control of, and to clarify, the legal principles." ${ }^{\text {"103 The }}$ Court echoed these sentiments in 2001 when ruling that de novo review is appropriate for analyzing a district court's ruling on the constitutional excessiveness of a punitive damages award. ${ }^{104}$ As I argue more fully in Parts III and IV, the Court's reasoning in these cases applies with equal force to sentencing: The content of the Sentencing Guidelines can only be given meaning through application, their principles are sorely in need of greater clarity, and allowing district judges too much discretionary leeway enables similarly situated persons to be treated differently depending on whose courtroom they happen to be in.

Importantly, the sentencing statute gives courts of appeals the tools to conduct the kind of de novo review that would add meaning and clarity to the Guidelines. Section 3742(e) requires the court of appeals, upon review of the record, to determine whether the sentence "departs from the applicable guideline range based on a factor that-(i) does not advance the objectives set forth in section 3553(a)(2); or (ii) is not authorized under section 3553(b); or (iii) is not justified by the facts of the case."105 The

100. Freed, supra note 20, at 1735; see also Cynthia K.Y. Lee, A New "Sliding Scale of Deference" Approach to Abuse of Discretion: Appellate Review of District Court Departures Under the Federal Sentencing Guidelines, 35 AM. CRIM. L. REV. 1, 27-28 (1997).

101. 517 U.S. 690,697 (1996).

102. Id.

103. Id.

104. See Cooper Indus., Inc. v. Leatherman Tool Group, Inc., 532 U.S. 424, 436 (2001) (arguing that de novo review will "assure the uniform general treatment of similarly situated persons," "clarify ... legal principles," and "unify precedent" (citations and internal quotation marks omitted)).

105. 18 U.S.C.A. § 3742(e) (West Supp. 2003). 
sentencing statute thus commands appellate courts in reviewing sentences to consider the purposes of sentencing-first in considering the objectives of $\S 3553(a)(2)$, and again in determining whether a sentence is "justified."

It is also worth noting that de novo review does not mean that no deference is given to the first step of departure analysis-the step at which the district court assesses aggravating or mitigating factors of a given case. The Supreme Court has held that even under a de novo standard of review, such findings of fact should be reviewed only for "clear error." 106 It is the second and third prongs of the departure decision-the district court's determination of whether mitigating or aggravating factors were adequately considered by the Commission and the court's assessment of the purposes of sentencing as they relate to the circumstances of the case-that are given plenary review.

\section{Applying De Novo Review to the Three Types of Departures}

The Guidelines Manual (as revised post-Feeney) describes three different types of departure decisions: "identified" departures, in which the grounds for departure are spelled out in the Manual; "unidentified" departures, in which a circumstance not identified by the Guidelines nonetheless makes the case so "exceptional" as to warrant departure; and so-called "heartland" departures, which involve circumstances mentioned in the Guidelines, but, given the facts of the case, were not "adequately taken into consideration" by the Commission. ${ }^{107}$ Professor Cynthia Lee suggests that because each of these types of departures requires a fundamentally different mode of analysis, each should be subject to a differing level of appellate scrutiny. ${ }^{108} \mathrm{I}$ argue that the type of analysis outlined above, in which courts of appeals give deference to the district court's factual determinations but review de novo the legal aspects of the departure decision, should apply equally to all three types of departures.

For "identified" departures, judges rely on the list of permissible grounds for departure in subpart $5 \mathrm{~K} 2$ of the Guidelines to determine whether a sentence should fall outside the Guideline range. ${ }^{109}$ For example, section 5K2.8 ("Extreme Conduct") states that "[i]f the defendant's conduct was unusually heinous, cruel, brutal, or degrading to the victim, the court may increase the sentence above the guideline range to reflect the nature of the conduct." In reviewing a $5 \mathrm{~K} 2.8$ departure, a court of appeals should give due deference to the district court's assessment of the facts, such as whether the defendant taunted the victim while committing his crime. But

106. Ornelas, 517 U.S. at 699.

107. U.S. SENTENCING GUIDELINES MANUAL § 5K2.0 (2003).

108. See Lee, supra note 100, at 41-46.

109. U.S. SENTENCING GUIDELINES MANUAL $\S \S 5 \mathrm{~K} 2.1-.23$. 
the court of appeals should review de novo whether those facts constitute "heinous, cruel, brutal, or degrading" conduct-because that is a legal assessment of what the Guidelines mean and are intended to cover.

"Unidentified" departures, by their very nature, provide less guidance as to appropriate factors to take into consideration. But even this type of departure decision occurs within strict limits. The commentary to section $5 \mathrm{~K} 2.0$ of the Guidelines notes that while "unidentified" departures are permissible, "it is expected that departures based on such unidentified circumstances will occur rarely and only in exceptional cases." 110 Similar to the determination of whether a punitive damages award is "excessive," the question of what is "exceptional" is fundamentally a legal analysis. It requires determining: (1) whether the circumstances of the case truly were not considered by the Sentencing Commission; and (2) whether the circumstances are extraordinary enough to merit departure, given the meaning and content of the entire Guidelines regime and the purposes of sentencing. Once the factual circumstances are determined (which, again, are given due deference), the remainder of this assessment is fundamentally a legal one that appellate courts are as well-situated to make as are district courts.

It is the third type of departure - "heartland" departures-that most troubled the courts in Rivera and Koon. These involve: (1) circumstances that were taken into consideration by the Sentencing Commission in establishing the Guidelines, but that are present in the offense "to a degree substantially in excess of, or substantially below, that which ordinarily is involved in that kind of offense"; $; 11$ or (2) offender characteristics that the Guidelines define as "not ordinarily relevant" in determining departures, but that are "present to an exceptional degree."112 In Rivera, then-Chief Judge Breyer explained that heartland decisions involve determining whether a case's circumstances "are usual or unusual, ordinary or not ordinary, and to what extent." 113 And since district judges see more ordinary offenders and are closer to the case at hand, Breyer argued they are better situated to determine what is and what is not usual. ${ }^{114}$

But this is a misguided approach to heartland analysis in that it relies on an unscientific survey of prior Guidelines cases. Paul Hofer and Mark Allenbaugh, who have both served as staff members of the Sentencing Commission, ask: "Do we really suppose that district judges see enough civil rights, environmental, or tax cases to develop a sense of what the

110. Id. $\S 5 \mathrm{~K} 2.0 \mathrm{cmt}$. 3(A)(ii) (emphasis added).

111. Id. $\S 5 \mathrm{~K} 2.0(\mathrm{a})(3)$.

112. Id. $\S 5 \mathrm{~K} 2.0(\mathrm{a})(4)$.

113. United States v. Rivera, 994 F.2d 942, 951 (1st Cir. 1993) (Breyer, C.J.).

114. Id. 
'typical' case looks like?"115 Hofer and Allenbaugh argue that it makes no sense to do a statistical analysis of past cases in order to determine a guideline's heartland because few such cases may exist, different district judges may come to different conclusions as to what is statistically typical, and these conclusions may differ from what was intended by the Sentencing Commission. $^{116}$

Still, even if we were to accept this statistical method as the proper way to make heartland determinations, de novo review would nevertheless be appropriate. Once the sentencing judge has made an assessment of the relevant facts (determining what about the case at hand may or may not be unusual), the departure decision requires an in-depth analysis of case law to determine what is "typical." The relevant universe of cases for such an analysis cannot be limited to the ones a given sentencing judge is familiar with, for that would create the kind of sentencing inconsistencies the SRA was designed to prevent. Rather, a proper analysis of relevant case law must look at comparable cases across districts and circuits throughout the country-an inquiry appellate courts are at least as well situated as district courts to make.

The correct way to determine a guideline's heartland, argue Hofer and Allenbaugh, is not through a statistical analysis using previous cases, but instead by looking at the guideline's purpose. Courts, in accordance with the commands of 18 U.S.C. $\S 3553(\mathrm{~b})$, should use "legislative history, guideline commentary, and other material," to discern the kind of cases the guideline was intended to cover. ${ }^{117}$ Once a court has defined the heartland, it can then determine whether the facts of the case differ "substantially" enough from the heartland to warrant departure. In this way, the task of defining a guideline's heartland and applying it to the facts of a given case is akin to deciding what constitutes "reasonable suspicion" or "probable cause." These are fundamentally legal and normative determinations in which district courts offer no special expertise and in which active appellate review can help bring clarity and uniformity.

Thus, the structure of the sentencing statute and the Guidelines, especially in the wake of the Feeney Amendment, suggests that de novo review is the proper standard for courts of appeals to employ when reviewing all departures from the Guidelines. Such a uniform standard has the added benefit of bringing greater clarity to the process of review in a way that Professor Lee's "sliding scale of deference"" 118 does not. In the

115. Paul J. Hofer \& Mark H. Allenbaugh, The Reason Behind the Rules: Finding and Using the Philosophy of the Federal Sentencing Guidelines, 40 AM. CRIM. L. REV. 19, 81 (2003).

116. See id.

117. Id. at $80-82$.

118. Lee, supra note 100 , at 1 . 
next Part, I argue that de novo review of sentencing departures also serves two important public policy objectives.

\section{The Public Policy Benefits of De Novo Review}

\section{A. Forcing the Courts of Appeals To Engage with the Purposes of Sentencing}

One of the most significant flaws of the Guidelines regime has been the unwillingness of courts at all levels to follow the sentencing statute's mandate to analyze the purposes of sentencing in deciding each case. ${ }^{119} \mathrm{~A}$ more active posture of review might force appellate courts - and thereby district courts - to grapple more fully with the sentencing process, as well as the changes (and potential injustices) brought about by the Guidelines regime. Koon's standard of deference has allowed appellate judges to hide behind the decisions of district courts and avoid responsibility for Guideline departures. It has also left district courts in the dark as to which departures are genuinely acceptable. For example, in Thurston the defendant, trying to win a departure based on his extensive service to the community, presented the First Circuit with a series of cases in which departures for "good works" had been granted by district courts and upheld by appellate courts. But the first Thurston panel found these cases unpersuasive primarily because "the circuit courts merely hold that there was no abuse of discretion."120 The courts of appeals, in other words, had clean hands; it was the district judges who had departed in each of these cases, and because their judgments were given deference, there was no way of really knowing whether or not the courts had properly interpreted the Guidelines. A de novo standard of review would force appellate courts not only to decide on their own whether the circumstances of a given case merit departure, but also to articulate an analytic framework for deciding when departures are appropriate.

That said, the general failure of the courts of appeals to contribute meaningfully to sentencing law cannot be blamed entirely on the abuse-ofdiscretion standard established by Koon in 1996. Prior to Koon, several scholars detailed how some appellate courts had been using their review powers to enforce compliance with narrow readings of the Guidelines rather than to define acceptable avenues for departure. Professor Daniel Freed argued that in the early years of the Guidelines, courts of appeals had acted like "super-sentencing commissions," curtailing departures "as though it

119. See Hofer \& Allenbaugh, supra note 115 , at 78-80; see also infra text accompanying notes $122-123$.

120. United States v. Thurston, Nos. 02-1966, 02-1967, 2003 U.S. App. LEXIS 15516, at *66 (1st Cir. Aug. 4, 2003), withdrawn, 358 F.3d 51 (1st Cir. 2004). 
was a $\sin$ to venture outside the guideline range." 121 Writing in 1992, Professor Marc Miller made the equally disturbing observation that neither district courts nor courts of appeals were considering the purposes of sentencing in their judgments, despite the fact that the Sentencing Reform Act mentions the purposes of sentencing eighteen times, ${ }^{122}$ and $\S 3553$ (a) and $\S 3742$ command courts to consider the purposes of sentencing. Miller wrote:

There are few model guideline sentencing decisions in which courts have considered the extent to which each of the purposes of sentencing applies to a kind of offense or offender. The lack of such analysis seems due in equal measure to the Commission's having discouraged judges from considering purposes, trial judges ignoring the mandates of $\S 3553(\mathrm{a})$, and the rigid and restrictive view of the judicial role taken by some federal courts of appeals ....

Koon's change in the standard of review had little effect on the dearth of principled sentencing decisions. The few scholars who have examined sentencing appeals in the wake of Koon point out that the above problems have, if anything, gotten worse. Michael Goldsmith and Marcus Porter write that after Koon, "chaos reigned," and that "[n]otwithstanding predictions to the contrary, Koon did not produce significantly higher affirmance rates of district court departure decisions."124 Professor Barry Johnson examined the different approaches of the circuit courts in the wake of Koon and found that those circuits that afforded considerable deference to district courts gave "the impression that departure review [was] purely ad hoc," and "provide[d] no guidance at all to sentencing judges in future cases." 125

The Feeney Amendment's call for de novo review can be viewed as a directive to bring order to such chaos. The benefit of de novo review is that when appellate courts do grant departures, other courts will be given license to follow their lead. This is why Mark Allenbaugh, in the course of blasting the other provisions of the Feeney Amendment, stated that de novo review might be the one provision worth saving: "Appellate courts now will be forced to provide district court judges with more certain guidance on when and to what degree departures are warranted. Consequently, de novo review

121. Freed, supra note 20 , at 1747.

122. Marc Miller, Purposes at Sentencing, 66 S. CAL. L. REV. 413, 417 (1992).

123. Id. at 463 .

124. Goldsmith \& Porter, supra note 6, at 72 (footnote omitted).

125. Barry L. Johnson, Discretion and the Rule of Law in Federal Guidelines Sentencing: Developing Departure Jurisprudence in the Wake of Koon v. United States, 58 OHIO ST. L.J. 1697,1751 (1998). 
actually may work to liberate judges rather than constrain them when they decide to depart."126 Equally important, courts of appeals can use the Feeney Amendment as an impetus to focus on $\S 3742(\mathrm{e})$ of the sentencing statute and begin a much-needed conversation among courts about the purposes of sentencing.

To be sure, the possibility exists that appellate courts will use their enhanced review powers to curtail most or all departures, both to conserve judicial resources and to avoid angering Congress. ${ }^{127}$ But although engaging in a principled analysis of departures (which the sentencing statute mandates) would certainly bring some additional workload to the federal appellate bench, the increase would likely be limited. In fiscal year 2001, of the more than 4000 sentencing cases heard by the courts of appeals, just 359 involved appeals of departure decisions, only twenty-five of which were brought by the government. ${ }^{128}$ It is difficult to imagine how the courts of appeals will be overburdened by giving this limited number of cases the kind of in-depth analysis they deserve. Whether the courts of appeals will be cowed into submission by Congress is a more difficult question. One hopes that appellate judges will keep in mind Senator Kennedy's message that the version of the Feeney Amendment that passed was not intended to eliminate departure decisions. Perhaps requiring courts of appeals to take more responsibility for sentencing decisions will inspire appellate judges to ensure that the sentences they review comport with the objectives of sentencing.

\section{B. The Development of a Common Law of Sentencing Departures}

A second, related policy consideration is the need for a common law of sentencing departures, the creation of which was one of the principal justifications for the SRA's appellate review provisions. ${ }^{129}$ But the

126. Mark H. Allenbaugh, Who's Afraid of the Federal Judiciary? Why Congress' Fear of Judicial Sentencing Discretion May Undermine a Generation of Reform, THE CHAMPION, June 2003, at 6, 11 .

127. The swift passage of the Feeney Amendment leaves little doubt that Congress believes courts grant too many departures. Indeed, the congressman who sponsored the Amendment delivered a less-than-subtle critique after Minnesota District Judge Paul Magnuson issued an opinion deeply critical of the Feeney Amendment, arguing that its purpose was to "intimidate and threaten judges." United States v. Kirsch, 287 F. Supp. 2d 1005, 1006 (D. Minn. 2003). Representative Feeney responded by telling a public radio audience: "I would remind the judge that he ought to get out the Constitution, where it's very clear that other than the United States Supreme Court, all of the other federal courts are only established by the will of the United States Congress." Judge Speaks Out Against Congress, Ashcroft (Minnesota Public Radio broadcast, Oct. 22, 2003), http://news.mpr.org/features/2003/10/22_stawickie_sentencing.

128. See REPORT TO THE CONGRESS, supra note 66, at 54-55; 2001 SOURCEBOOK, supra note 66, at 108-09 tbls.57-58.

129. See Comprehensive CRIME CONTROL ACT OF 1983, S. ReP. No. 98-225, at 150-51 (1983), reprinted in 1984 U.S.C.C.A.N. 3332, 3333-34; see also Norval Morris, Towards Principled Sentencing, 37 MD. L. REV. 267, 284 (1977) (suggesting that appellate review is an 
development of a common law of sentencing departures has been stymied in the past for three reasons: (1) Prior to the Feeney Amendment, district courts could issue their reasons for departure orally and thus were not required to provide the written records that form the basis for the development of a common law; (2) deferential review has allowed inconsistent, district-by-district definitions of key Guideline terms; ${ }^{130}$ and (3) appellate courts have taken a backseat to the rulemaking authority of the Sentencing Commission. ${ }^{131}$ Professor Reitz notes that "because the circuit courts have afforded such deference to the lawmaking choices of the Commission, the appellate bench itself has forsworn any important substantive lawmaking role." 132 For the Guidelines to be administered consistently and justly, this must change. The Commission continues to provide neither legislative history nor comprehensive explanations of the rules it promulgates. Nor does it list cases it sees as being within the heartland of the various guidelines. As a result, many places in the Guidelines remain unclear, undefined, or ambiguous, particularly in regard to when departures are and are not appropriate. Without active involvement of the courts of appeals, the role of filling in the gaps has been left to district courts-a situation that necessarily leads to less uniformity in sentencing.

In Koon, however, the Supreme Court suggested that there was no place for common law development in sentencing departures because they involve facts that are "'multifarious, fleeting, special, [and] narrow," and require the "consideration of unique factors that are little susceptible ... of useful generalization." "' 133 . This reasoning might have made sense under the pre-Guidelines regime, in which sentencing determinations were so case-specific that general rules would likely carry little meaning. But the Guidelines have turned sentencing into a rule-based exercise, and it is imperative for the courts of appeals to delineate what the rules are, particularly when it comes to departure determinations, in which the Sentencing Commission has provided little or no guidance. In Thurston, for

\footnotetext{
"obvious precondition of the evolutionary and principled development of a common law of sentencing"). Professor Morris was an early proponent of sentencing reform who helped inspire the creation of the Guidelines.

130. See Panel II: The Effects of Region, Circuit, Caseload and Prosecutorial Policies on Disparity, 15 FED. SENTENCING REP. 165, 166 (2003).

131. See Reitz, supra note 18 , at 1471.

132. Id.

133. Koon v. United States, 518 U.S. 81, 99 (1996) (quoting Cooter \& Gell v. Hartmarx Corp., 496 U.S. 384, 404 (1990)). A portion of the Court's analysis borrows from a 1971 law review article that was not specifically intended to apply to sentencing. See Maurice Rosenberg, Judicial Discretion of the Trial Court, Viewed from Above, 22 SYRACUSE L. REV. 635, 662 (1971) ("One of the 'good' reasons for conferring discretion on the trial judge is the sheer impracticability of formulating a rule of decision for the matter in issue. Many questions that arise in litigation are not amenable to regulation by rule because they involve multifarious, fleeting, special, narrow facts that utterly resist generalization .....").
} 
example, one of Judge Harrington's departures was for "good works," 134 but what constitutes a good work? How do good works relate to the language and structure of the sentencing statute or comport with the purposes of sentencing? Moreover, in order to grant a heartland departure, the Guidelines require courts to find the circumstances of any case "exceptional," but even this basic term is not defined. ${ }^{135}$

If a primary goal of the SRA is for sentencing to be consistent across districts, each sentencing judge cannot be permitted to define these terms herself. Rather, appellate courts must have the power to say what the law is, not merely to define its outer boundaries. This is the same reason the Supreme Court in Ornelas held that de novo review was appropriate for probable cause determinations: De novo review allows appellate courts to clarify legal principles and unify precedent. ${ }^{136}$ In applying this rationale to sentencing, the goal is to develop "a jurisprudential approach to those occasions in which it is appropriate to set guideline presumptions aside." 137

\section{THE HOLLOW ARGUMENTS IN FAVOR OF AN ABUSE-OF-DISCRETION STANDARD OF REVIEW}

Given the structural and policy arguments I have spelled out in favor of de novo review, it is worth considering whether compelling reasons exist that weigh in favor of an abuse-of-discretion standard. In the twenty years since the passage of the Sentencing Reform Act, judges and scholars have advanced three substantial justifications for why appellate courts should defer to the judgments of their district court colleagues: (1) District judges, because of their day-to-day experience with sentencing, know more than appellate judges and are thus better equipped to make sentencing decisions; (2) district judges are able to get a "feel" for an individual case in a way that an appellate court, reviewing a paper trail, cannot; and (3) strong appellate review would hurt the Sentencing Commission's ability to learn from the judgments of district courts. This Part discusses why these arguments do not outweigh the potential benefits of de novo review.

\section{A. Greater Knowledge}

In Rivera, then-Chief Judge Breyer explained his preference for a deferential standard of review by noting that a district court is "likely to have seen more ordinary Guidelines cases, for appellate courts hear only

134. United States v. Thurston, 358 F.3d 51, 54 (1st Cir. 2004).

135. See U.S. SENTENCING Guidelines MANUAL § 5K2.0(a) (2003).

136. Ornelas v. United States, 517 U.S. 690, 697 (1996).

137. Reitz, supra note 18 , at 1455. 
the comparatively few cases that counsel believe present a colorable appeal." ${ }^{138}$ Likewise, in Thurston, the Federal Defender Office submitted an amicus curiae brief in support of Thurston's appeal, arguing that "district court judges are far better informed about sentencing than are circuit judges," and noting that Massachusetts district judges "attend sentencing institutes [and] speak about sentencing at legal education programs." 139

This theory-that district courts possess greater knowledge-is also reflected in the scholarly literature on sentencing. ${ }^{140}$ Professor Freed argues that appellate courts should accord greater deference to the experience of district courts in part because " $[\mathrm{t}]$ he appeals court is remote from the universe of cases that make equality and proportionality in punishment, across different defendants and crimes, issues of transcendent importance." 141

But while this argument might have been compelling in the early years of the Guidelines, when most appellate judges had little to no experience with sentencing, appellate courts now have seventeen years of reviewing sentences under their belts. While it is true that more than $90 \%$ of sentencing decisions each year do not get appealed, this still leaves more than 4000 sentencing appeals a year. ${ }^{142}$ Professor Reitz notes that about $60 \%$ of all criminal appeals (including habeas and conviction appeals) are sentencing appeals; "review of punishment decisions is now a more frequent occurrence in the federal circuit courts than the review of all other issues in criminal cases combined." 143 Also, because district judges do not see many of any single type of departure case, their experience in sentencing gives them no institutional advantage. ${ }^{144}$ Professor Ian Weinstein points out that in one sense courts of appeals can bring more knowledge to a case than can district courts, because appellate judges "have the benefit of the views of the district judge and the other members of their panels." 145

Furthermore, while it is clear that many district judges know more about sentencing than do appellate judges, the larger issue is whether this makes any substantive difference. In countless circumstances in both

138. United States v. Rivera, 994 F.2d 942, 951 (1st Cir. 1993) (Breyer, C.J.).

139. Memorandum of Amicus Curiae Federal Defender Office and District of Massachusetts Criminal Justice Act Board in Support of Defendant's Petition for Panel Rehearing and Rehearing En Banc at 6, Thurston (No. 03-1967).

140. See, e.g., Freed, supra note 20, at 1728; Lee, supra note 100, at 33.

141. Freed, supra note 20 , at 1728.

142. See 2001 SOURCEBOOK, supra note 66 , at 53 tbl.26, 105 tbl.56. Of the 54,851 cases in 2001 for which the Commission had sufficient data, approximately 4200 were appealed. Id.

143. Reitz, supra note 18 , at 1491 . Of the 5807 criminal appeals heard by the circuit courts in 2001 (a number that excludes those for which the Commission had insufficient data), more than 4000 involved sentencing questions, whereas fewer than 3000 involved one or more nonsentencing issues. See 2001 SOURCEBOOK, supra note 66, at 101 tbl.55.

144. See Weinstein, supra note 6 , at 522.

145. Id. 
criminal and civil cases, a given trial judge will have greater expertise than do the judges assigned to hear the case on appeal. Yet that doesn't mean appellate judges must blindly defer to their more knowledgeable district court colleagues. Rather, what matters is that appellate courts and trial courts have access to the same tools and information necessary to render a decision. In Thurston, the Federal Defender Office maintained that the district court's critical advantage lay partly in a compendium of all Massachusetts district court downward departures since the enactment of the Guidelines. ${ }^{146}$ Yet these data were available to both Judge Harrington and the First Circuit panel. Furthermore, with the Feeney Amendment's extensive reporting requirements, which force district courts to submit to the Sentencing Commission every sentence issued along with a written report explaining the reasons for any departures, ${ }^{147}$ courts around the country will now have unprecedented access to the departure decisions of their colleagues.

In one sense, it could even be advantageous for an appellate court to have less experience in criminal sentencing, so as to not be prejudiced by personal experience. For even if heartland departures are based on what is statistically "unusual" or "extraordinary," the relevant universe of typicality extends beyond those cases a trial judge has seen during his or her tenure, to all cases across the country. An appellate court may therefore be in a better position to dispassionately evaluate the unusualness of a given case by leaving personal experience out of the calculation and instead relying on how courts around the country have dealt with similar issues.

\section{B. Greater "Feel"}

The second assertion made in favor of abuse-of-discretion review is that district judges possess a superior "feel" for the case at hand and are thereby in a better position to dispense genuine justice. Commentators frequently cite a section of the Diaz-Villafane opinion to explain why this is so: "District courts are in the front lines, sentencing flesh-and-blood defendants. The dynamics of the situation may be difficult to gauge from the antiseptic nature of a sterile paper record. Therefore, appellate review must occur with full awareness of, and respect for, the trier's superior 'feel' for the case." 148 Professor Freed further explains the gap between district court and appellate court perspectives:

146. Memorandum of Amicus Curiae Federal Defender Office and District of Massachusetts Criminal Justice Act Board in Support of Defendant's Petition for Panel Rehearing and Rehearing En Banc, supra note 139, at 6.

147. See 28 U.S.C.A. $\$ 994(w)$ (West Supp. 2003).

148. United States v. Diaz-Villafane, 874 F.2d 43, $49-50$ (1st Cir. 1989). 
Appeals court judges are reviewers, opinion writers, and rulemakers. They no longer look defendants in the eye, study presentence reports, or struggle with assessing whether an offender is beginning or ending a criminal career, appears to be dangerous or harmless, is a minnow in a sea of big fish, or has gone astray under unusually stressful circumstances and will not offend again. Appellate judges no longer see large numbers of worried or stunned faces, or multiple defendant cases covering the full range of criminal responsibility. ${ }^{149}$

Freed's analysis, however, brings us back to the question of under what circumstances a court is permitted to rely on an open-ended evaluation of the "whole person," for which it has a better feel. As discussed in Part II, district courts have great leeway in choosing a sentence within the Guideline range and, after the decision to depart has been made, the extent of the departure. But the sentencing statute limits the degree to which judges can rely on their feel of a case when making a departure decision. On the one hand, a sentencing judge can (and should) rely on her superior feel for the case in making the factual assessment of what about a case is aggravating or mitigating. But the remainder of the departure inquiry is confined to an analysis of the "guidelines, policy statements, and official commentary of the Sentencing Commission," 150 in which the feel of the given case is not relevant. This is why the court's discussion of the "trier's superior "feel"' in Diaz-Villafane came not in its evaluation of the departure decision itself, but only after that decision had been deemed appropriate, in determining whether it was proper for the district court to depart upward so severely.

In some situations, a sentencing judge may believe her feel for the case is central to the decision to depart. In such cases, the judge can take steps to ensure the appellate court understands why this is so. For example, Massachusetts District Judge Gertner recently granted a good works departure for a defendant's extraordinary contributions to his community. ${ }^{151}$ In her sentencing memorandum, she wrote that at the defendant's sentencing hearing, "one hundred people filled the courtroom to overflowing ... and returned for each of the three days (which significantly, were not consecutive) no matter what the distances they had to travel." "52 Judge Gertner wrote that she described the courtroom scene "in order to give the reader-including any reviewing court-the kind of data to which the First Circuit referred in United States v. Diaz-

149. Freed, supra note 20 , at 1728.

150. 18 U.S.C. $\S 3553$ (b) (2000).

151. See United States v. Mehta, No. CRIM.01-10180-NG, 2004 WL 418119, at *1 (D. Mass. Mar. 3, 2004) (Gertner, J.).

152. Id. 
Villafane." 153 She added: "Unfortunately, I do not believe that my words can do justice to the courtroom scene or the nature of the testimony. Henceforth I will videotape the proceedings." 154 Judge Gertner's initiative (following in Judge Weinstein's footsteps) should be applauded. However, even in cases in which a district judge's written assessment of the factual underpinnings of a departure may not fully capture what really occurred, the feel of the courtroom has no bearing on the parts of the departure decision that this Note advocates should be reviewed de novo-specifically, the court's analysis of the purposes of sentencing and the assessment of what the Guidelines mean.

Given that the primary goal of the SRA is to curb sentencing disparities, limiting judges' reliance on their "feel" for cases during sentencing makes sense. After all, one of the central purposes of appellate review, according to Professor Judith Resnik, is "the distillation of a problem - the provision of a delayed consideration of a dispute, after issues have been considered before." 155 Consider the following example: Ninth Circuit Judge Alex Kozinski recently explained to a reporter how in 1988, after accepting a temporary assignment in district court, he had to sentence a twenty-three-year-old woman who was convicted of possessing five kilograms of cocaine. The Guidelines had just been enacted, and Judge Kozinski had already garnered a reputation as a law-and-order conservative with little sympathy for criminals. But he sentenced the woman to just six months in jail, plus community service and probation, as opposed to the ten years asked for by the prosecution. Given a chance to reconsider his decision, he declined because " $[t]$ here she was in front of me with her family. I just felt like, having set her on this track, I had a responsibility to her."156 Judge Kozinski's feel for the case arguably corrupted his legal judgment - something the passage of the SRA was designed to prevent. In contrast, appellate judges have the ability to distill the issues involved in sentencing and are not biased by their personal experience with the defendant. They therefore are, if anything, more qualified than district judges to assess the legal bases for departures.

\section{The Role of the Sentencing Commission}

The third significant argument given in favor of the abuse-of-discretion standard is that greater appellate involvement in sentencing would hinder the Sentencing Commission's efforts to monitor and learn from the

153. Id. at *1 n.3.

154. Id.

155. Judith Resnick [sic], The Death of Appeals?, 5 FifTH CIRCUIT REP. 637, 642 (1988).

156. Emily Bazelon, The Big Kozinski, LEGAL AFF., Jan./Feb. 2004, at 24, 28 (internal quotation marks omitted). 
decisions of district courts. In United States $v$. Wright, then-Judge Breyer wrote: "Too intrusive a standard of appellate review could impede the Commission's efforts to learn from district courts' experience."157 The argument is that if appellate courts were to put their weight either in favor of or in opposition to a departure determination, district courts would have no choice but to follow these prescriptions rather than determine on their own what sentences are appropriate. This hypothetical reaction would then deprive the Commission of valuable information. Steven Zipperstein, a former Assistant U.S. Attorney who has written extensively about the Guidelines, took the argument further in his warning against de novo review: "[A]ppellate courts exceed their authority when they effectively add new provisions to the guidelines, when they announce new criteria permitting departures, and when they otherwise use the power of de novo review to announce rules that undermine the purposes of the guidelines."158

This argument is flawed in three ways. First, the Sentencing Commission already has plenty of information to use in reviewing the Guidelines. Over the past seventeen years, the Commission has received documentation on hundreds of thousands of cases and tens of thousands of departures. ${ }^{159}$ It is difficult to imagine how de novo review would limit the information available to the Commission to the point where it would be unable to fulfill its statutory duties. This outcome is particularly unlikely considering the Feeney Amendment's new reporting requirements, ${ }^{160}$ which will lead to considerably more rather than less information and clarity about the decisions made by district courts.

Second, many district judges will be willing to speak out regardless of the rulings of their appellate bench. Then-Judge Breyer's argument assumes that when district judges believe a departure is appropriate-but don't give one due to the specter of being reversed on appeal-they will keep quiet about it. However, the evidence in the months since the passage of the Feeney Amendment suggests that this is not always true, thus leaving open the opportunity for the Sentencing Commission to continue to learn from district courts in the most difficult cases. For example, in October 2003, Judge Webb of the District of North Dakota, after having a sentence of his vacated by the Eighth Circuit, wrote a "Dissent upon Imposition of Sentence" explaining his "honest disagreement" with the appellate court's

157. 873 F.2d 437, 444 (1st Cir. 1989) (Breyer, J.) (citation omitted).

158. Steven E. Zipperstein, Certain Uncertainty: Appellate Review and the Sentencing Guidelines, 66 S. CAL. L. REV. 621,638 (1992).

159. In fiscal year 2001 alone, the Commission received documentation on 59,897 cases sentenced under the Guidelines. Of the 54,851 cases for which the Commission had sufficient data, $18.3 \%$ were non-governmental-assistance downward departures. See 2001 SOURCEBOOK, supra note 66 , at 53 tbl. 26 .

160. See 28 U.S.C.A. $\S 994(w)$ (West Supp. 2003). 
reading of the Guidelines. ${ }^{161}$ That same month, Judge Magnuson of the District of Minnesota refused to depart in a fraud case, but added in his opinion: "If the Court were to depart ... [t]he Attorney General would then report the departure to Congress, and Congress could call the undersigned to testify and attempt to justify the departure .... [T] he Court is scared to depart."162 And of course in Thurston, despite the First Circuit's exercise of de novo review, Judge Harrington made clear his displeasure with the panel's application of the Guidelines. Thus, the fear that less deferential review might leave the Sentencing Commission ignorant of information crucial to assessing the Guidelines seems exaggerated.

Third, the Commission has had seventeen years to clarify and revise the Guidelines, yet in many circumstances has abrogated its responsibility. The original introduction to the Guidelines Manual states: "By monitoring when courts depart from the guidelines and by analyzing their stated reasons for doing so, the Commission, over time, will be able to create more accurate guidelines that specify precisely where departures should and should not be permitted." 163 The problem is that when the Commission plays the role of Supreme Court to resolve conflicts among the circuits, it almost never explains or justifies its resolutions, turning the Guidelines into "administrative diktats" rather than carefully reasoned and explained rules. ${ }^{164}$

Perhaps it is time to give the courts of appeals the opportunity to make sense of the Guidelines. Appellate courts that wisely exercise their powers of de novo review can create a substantive body of law complete with explanations of their decisions, unlike the "diktats" of the Commission. Importantly, as explained in Part II, the sentencing statute commands courts of appeals to look beyond the confines of the Sentencing Manual when considering departures and to ensure that a given sentence is in accord with the purposes of sentencing. ${ }^{165}$ Also, the Feeney Amendment explicitly prohibits the Sentencing Commission from promulgating any new guideline that adds new grounds for downward departures until May 1, 2005, ${ }^{166}$ and reduces the ability of judges to influence the future content of the Guidelines by ensuring that judges can never be a majority on the Commission. ${ }^{167}$ Thus appellate courts have the power to achieve what the Commission has thus far failed to do and is, at least temporarily, prohibited from doing: They can define and explain how specific departures comport with the general principles of sentencing.

161. United States v. Dyck, 287 F. Supp. 2d 1016, 1017 (D.N.D. 2003) (Webb, J.).

162. United States v. Kirsch, 287 F. Supp. 2d 1005, 1006-07 (D. Minn. 2003) (Magnuson, J.).

163. U.S. SENTENCING GUIDELINES MANUAL § 1A1.1 editorial note pt. A(4)(b) (2003).

164. See STITH \& CABRANES, supra note 23 , at $95-99$.

165. See 18 U.S.C. $\$ 3742(\mathrm{e})(2000)$. The Feeney Amendment did not change this command.

166. See PROTECT Act, Pub. L. No. 108-21, § 401(j)(2), 117 Stat. 650, 673 (2003).

167. See id. $\S 401(\mathrm{n}), 117$ Stat. at 675-76 (amending 28 U.S.C. $\S 991(\mathrm{a})$ ). 
Taken together, the arguments in favor of the Koon abuse-of-discretion standard are outweighed by the potential for de novo review to inspire the courts of appeals to take more responsibility for the fairness of the Guidelines regime and to create a substantive common law of sentencing departures. A reexamination of Thurston further supports this argument and also provides the opportunity to show what de novo review, when exercised with wisdom and forethought, would look like in practice.

\section{REVISITING THURSTON}

After the First Circuit's initial decision, William Thurston petitioned the panel to rehear the case and the full court of appeals to take the case en banc. The Federal Defender Office submitted an amicus brief sharply critical of the First Circuit's use of de novo review. In response, the panel withdrew its opinion from publication. In February 2004, the First Circuit issued a new ruling, this time with a more careful analysis of the Feeney Amendment. But the court again rejected Judge Harrington's departures. ${ }^{168}$

Judge Harrington had provided two grounds for departing from the Guidelines: (1) The president of the company, who had pled nolo contendere, had received only three months' probation for the same offense; and (2) Thurston had demonstrated an extraordinary record of service to his community. ${ }^{169}$ The First Circuit's rejection of the first departure ground was uncontroversial, as Judge Harrington had ignored the circuit's case law on the issue. ${ }^{170}$ The good works departure, on the other hand, would likely have been upheld had the First Circuit reviewed it only for abuse of discretion. This was a "heartland" departure, as it involved circumstances mentioned in, but not fully prohibited by, the Guidelines. Section $5 \mathrm{H} 1.11$ of the Guidelines states: "Military, civic, charitable, or public service; employment-related contributions; and similar prior good works are not ordinarily relevant in determining whether a sentence should be outside the applicable guideline range." "71 Judge Harrington, therefore, had to show that Thurston's good works were exceptional-that the circumstances in this case were different enough from the good works

168. See United States v. Thurston, 358 F.3d 51, 55 (1st Cir. 2004).

169. Id. at 54 .

170. As far back as 1991, the First Circuit had concluded that, absent a showing of additional circumstances not considered by the Commission, the Guidelines preclude sentencing judges from departing downward based on "a perceived need to equalize sentencing outcomes for similarly situated codefendants." United States v. Wogan, 938 F.2d 1446, 1448 (1st Cir. 1991). At sentencing, Judge Harrington did not refer to any such circumstances, relying exclusively on the disparity between Thurston's sentence and that of the company president. See Thurston, 358 F.3d at 78. As a result, this ground for departure would likely have been reversed regardless of the standard of review.

171. U.S. SENTENCING GUIDELINES MANUAL $§ 5 H 1.11$ (2003) (emphasis added). 
considered by the Commission as to make this case fall outside the heartland of section $5 \mathrm{H} 1.11$.

As discussed in Part II, the determination of whether Thurston's case met these criteria involves two distinct inquiries. First, the sentencing court must determine what about the case is especially mitigating. This assessment of the quantity and quality of Thurston's good works is a factual determination that should be given deference by the court of appeals. Second, the court must determine what has been "adequately taken into consideration" by the Sentencing Commission, to see whether the mitigating circumstances warrant departure in light of the purposes of sentencing. In other words, the court must define the guideline's heartland, a determination that should be reviewed de novo.

Judge Harrington made several factual conclusions about Thurston's good works: As a member of the Church of Latter-Day Saints, Thurston tithed ten percent of his income; he devoted hours every week to unpaid service with the church; he took family members and others into his home, including a woman undergoing rehabilitation at a local medical center; and he once laid sod for an infirm neighbor. ${ }^{172}$ These conclusions should only be reviewed for clear error since Judge Harrington, having viewed all the testimony in person, was in a far better position than the First Circuit to evaluate their veracity. But at sentencing Judge Harrington made an additional conclusion: "[I]n over fourteen years of sentencing defendants, it's my judgment that no one had a more extraordinary devotion to charitable work, community service, and especially ... to his church."173 How much weight should the First Circuit lend to such a statement?

The basic factual veracity of Judge Harrington's remark should be accepted, absent clear evidence to the contrary, but it does not necessarily follow that departure is warranted. As established in Part II, the individual experience of a district court judge cannot be determinative as to what is unusual or extraordinary: Judge Harrington may have had the misfortune of seeing throughout his time on the bench only the most selfish offenders in Massachusetts, whereas another judge may have seen ten defendants just like Thurston. The proper way to define the heartland of section $5 \mathrm{H} 1.11$ is to examine the Guidelines themselves, including policy statements and commentary, and to consider the purposes of sentencing as applied to the facts of the case, in order to discern the kind of cases the guideline was intended to cover. If other good works cases are to be considered, the relevant universe of case law is nationwide, not limited to Judge Harrington's courtroom.

173. Id. (internal quotation marks omitted). 
In certain ways, the First Circuit attempted to undertake this kind of inquiry. The panel began by reviewing prior good works departure decisions, and it looked not just within the First Circuit, but also to the precedents of the Fourth, Sixth, and Eighth Circuits. ${ }^{174}$ The panel did not, however, cite any district court cases either within or outside of the District of Massachusetts. ${ }^{175}$ The panel noted that the case law, which offered "little guidance," did suggest one important conclusion: Good works cannot be measured by quantity alone. ${ }^{176}$ Accordingly, the panel noted that "a corporate executive like Thurston is better situated to make large financial contributions than someone for whom the expenses of day-to-day life are more pressing; indeed, business leaders are often expected, by virtue of their positions, to engage in civic and charitable activities." 177

The panel then considered the purposes of sentencing as applied to Thurston's case, and stated that "[o]ne of the goals of the entire guidelines regime was to minimize discrepancies in the treatment of 'white collar' and 'blue collar' crimes." 178 It also noted that "[h]ealth care fraud is a serious crime and the federal interest in combating it is powerful," $" 179$ and that Thurston's executive position "gave him the resources to undertake many of his charitable works." 180 The panel's first opinion also mentioned "the need to deter other executives from similar lawbreaking"; ${ }^{181}$ it is not clear why this was left out of the revised opinion.

Taking all of these factors into consideration-each of which has a fundamentally legal, not factual, basis - the court concluded that Thurston's good works did not fall outside the heartland of section $5 \mathrm{H} 1.11$, finding that they were "admirable," but not "exceptional."182 The panel then remanded the case for imposition of the statutory maximum sentence of 60 months. ${ }^{183}$

While laudable in some respects, the panel's decision should not be considered a model of de novo review. One problem stems from the panel conducting its heartland inquiry with almost no guidance from the district court, as Judge Harrington did not refer to the purposes of sentencing or to other Guideline cases when granting Thurston the good works departure. ${ }^{184}$

174. Id. at 80 .

175. See id.

176. $I d$.

177. $I d$.

178. $I d$.

179. Id. at 81 .

180. Id.

181. United States v. Thurston, Nos. 02-1966, 02-1967, 2003 U.S. App. LEXIS 15516, at *71 (1st Cir. Aug. 4, 2003), withdrawn, 358 F.3d 51.

182. Thurston, 358 F.3d at 81 .

183. Id. at 82 .

184. See id. at $78 \mathrm{n} .25$. Judge Harrington did, on the other hand, address the purposes of sentencing in granting the departure based on the disparity between Thurston's sentence and that of the company's president. See id. ("Congress sought reasonable uniformity in sentencing by narrowing the wide disparity in sentences imposed for similar criminal offenses committed by 
While de novo review gives considerable authority to the courts of appeals, it does not transform them into courts of first instance. The proper move for the First Circuit would have been to remand the case to Judge Harrington without an outright rejection of the good works departure, but rather with a directive to undertake the kind of inquiry into the purposes of sentencing and the meaning of the heartland that is commanded by the sentencing statute and the Guidelines. Such a process would ensure that when appellate courts sign off on-or reject-grounds for departure and thereby contribute to a common law of sentencing, they only do so when fully informed.

Another problem with the panel decision is that it gave no guidance as to what criteria would ever be enough for a court to grant a good works departure. Judge Gertner explains:

As the First Circuit typically does, it cited a host of cases in which the departure showing was inadequate, and not one in which the case was legitimately made. It may be enough for appellate courts to say over and over again, "No, this case is not it, nor that, nor that." As a trial judge with a human being before me, I have to do more. The Court cannot be saying that no white collar offender can ever satisfy the strictures of this departure. ${ }^{185}$

Of course, a common law of sentencing departures must develop over time, over hundreds or even thousands of cases. It is easy to ask a case to do too much. But the First Circuit panel's failure to cite a single case in which a good works departure was properly granted is a glaring omission.

Thurston thus shows the potential for de novo review-if properly employed-to inspire both district and appellate judges to more fully consider the purposes of sentencing in making departure determinations. As with much of the Guidelines, the Sentencing Commission's enactment of section $5 \mathrm{H} 1.11$ created a "diktat" with little guidance as to what does or does not fall under the guideline or what its purposes are. Crucial terms such as "good works" and "ordinarily relevant" were left-and remain-undefined, and the basic question as to why good works should ever be a reason to lessen a sentence remains unanswered. The task of definition has therefore been left to the courts.

Had the First Circuit panel simply deferred to the discretion of Judge Harrington, the meaning of good works as applied to Thurston would have been contingent on the individual experience of a single district judge,

similar offenders.... [I]t is, in my judgment, a violation of the fundamental purpose of the Sentencing Commission Guidelines to impose a sentence which is not at least somewhat similar to that incurred by a coconspirator who was more involved in the conspiracy $t[h] a n$ this defendant." (internal quotation marks omitted)).

185. United States v. Mehta, No. CRIM.01-10180-NG, 2004 WL 418119, at *5 (D. Mass. Mar. 3, 2004) (Gertner, J.). 
leaving other sentencing judges with less guidance as to how to properly interpret the guideline. But by using de novo review and making at least a limited attempt to grapple with the underlying purposes of section $5 \mathrm{H} 1.11$, the First Circuit provided some important guidance regarding the exercise of this kind of departure.

\section{CONCLUSION}

Judges and scholars are right to be troubled by many of the provisions of the Feeney Amendment. Its central justification-that rampant departure decisions in the wake of Koon threatened to undermine the uniformity of sentencing brought about by the Guidelines-was dubious at best. It is not surprising, then, that the legal community is working furiously to have the Amendment repealed.

But two provisions of the Amendment-de novo review and the requirement that district courts put their reasons for sentencing departures into writing-are worth keeping. One of the great shortcomings of the Guidelines regime has been the failure of courts at all levels to engage in principled analyses of sentencing rather than perfunctory enforcement of administrative diktats cloaked as "guidelines." A central purpose of this Note is to suggest that courts of appeals should use the Feeney Amendment's de novo provision as an impetus to bring principle and meaning to the Guidelines at long last. If they do so, over time the Guidelines will become clearer and sentencing will become fairer and more consistent. Given the historical failure of the Sentencing Commission to explain the purposes behind the Guidelines and Congress's new limits on the Commission's powers, the courts of appeals are the only actors in the system capable of bringing about such dramatic change.

Of course, if the courts of appeals-out of either expedience or fearuse de novo review simply as a bigger weapon with which to curtail departures, we will be left with the kind of inflexible and unfair system Congress rejected when it modified the House version of the Feeney Amendment. We must hope that de novo review, by forcing appellate judges to take firsthand responsibility for the outcomes of their sentencing decisions, will inspire the courts of appeals to become strong and active voices in favor of a more just and principled system of punishment. 